can see how the leg-like anchor domains of FliD bind to FlgL in a similar manner to the structure of the D0-D1 domain of FliC over the symmetry mismatch as well as the depression and space inside the cap complex for promoting assembly.

\section{PS013 バイメタルカンチレバーを用いた褐色脂肪細盷の発熱量の定量的解析}

Quantitative analysis of heat production of brown adipocytes using bimetal cantilever

Masaaki Sato ${ }^{1}$, Masaya Toda ${ }^{2}$, Naoki Inomata ${ }^{2}$, Yuichi Inoue ${ }^{1}$, Takahito $\mathrm{Ono}^{2}$, Akihiko Ishijima ${ }^{1}\left({ }^{1} I M R A M\right.$, Tohoku Univ., ${ }^{2}$ Grad. Sch. Eng., Tohoku Univ.)

Brown adipocyte is a cell specified for metabolic heat production. From a calorimetry using $10^{8}$ numbers of the cells, the cell is thought to produce $n W$ ordered heat. However, the character of each cell cannot be investigated by the calorimetry. To reveal the character, the measurement technique for heat production of a single cell is needed. So we developed a bimetal cantilever ( 750 $\times 40 \mu \mathrm{m})$, which is composed of gold (100 $\mathrm{nm}$ in thickness) and silicon nitride (200 $\mathrm{nm}$ in thickness). When the cantilever senses heat, it bends due to the difference of the coefficient of thermal expansion of the metals. We tried to measure the heat produced by a small number of the cells using the cantilever. The displacement of cantilever was measured under a conventional microscope when the 5-6 cells reached about $2 \mu \mathrm{m}$ away from the tip of cantilever. After the addition of norepinephrine (final $1 \mu \mathrm{M}$ ), the displacement of the cantilever increased as time passed on. After $60 \mathrm{~min}$ from the addition, the displacement of cantilever became maximum value $(60 \mathrm{~nm})$. If the heat which the cantilever detected has escaped only at the end of the cantilever, the value corresponds to that the temperature of the tip of the cantilever has increased $10 \mathrm{mK}$. After further $90 \mathrm{~min}$, the displacement was not observed. We would like to discuss the activation and inactivation of heat production of the cell together with lipid consumption of the cell and expression level of protein which is involved in heat production.

\section{PS014 細盷シート 1 軸延伸測定法による時間依存力学測定}

Time-dependetn Poisson's ratio and Power-law rheology of cell sheet in uniaxial stretching experiment

Masahiro Tsuchiya, Yusuke Mizutani, Takaharu Okajima (Graduate School of Information Science and Technology, Hokkaido Univ.)

Mechanical properties of living cells are strongly related to their physiological functions such as migration, division and restructuring of their intracellular structures. Rheological properties of living cells have been extensively investigated by various microbead techniques, atomic force microscopy and single cell stretching method. These studies showed the single cell exhibited a power-law behavior in frequency domains. The Poisson's ratio of living cells is one of the important modulus and related with some time dependent modulus. Moreover, studies regarding polymer materials revealed that the Poisson's ratio was a function of time. However, the time-dependent Poisson's ratio of cells has not been measured. In this study, we measured the Poisson's ratio of cells as a function of time during stress relaxation of cell sheet composed of NIH3T3 cells with a size of ca. $500 \times 400 \mu \mathrm{m}$. We found that the Poisson's ratio of cell increased with time and became time constant. As the actin filaments were disrupted, the time dependent Poisson's ratio reduction is rapidly changed. The results indicated that the time dependent Poisson's ratio was strongly related to the contraction of actin structures.

\section{PS015原子間力顥微鏡を用いた単一細盷レオロジーの高速・精密測定法の 開発}

High-speed measurement of single cell rheology with an atomic force microscope

Ryosuke Takahashi, Satoshi Ichikawa, Takaharu Okajima (Graduate School of Information Science and Technology, Hokkaido University)

Single cell measurements of cell mechanics are crucial not only for understanding various cell functions such as migration and proliferation but also for distinguishing different types of cells. It has been reported that the elastic property of cancer cells is smaller than that of normal cells $[1,2]$. We obviously observed that cancer cells are softer and more fluid than normal cells and found the difference of the ensemble distribution of rheological properties between normal and cancer cells such as human mammary epithelial cells (MCF-10A) as normal cell and human mammary adenocarcinoma cells (MCF-7) as cancer cell [7]. To improve throughput of cell measurements, we developed an AFM system for the measurement of rheological properties of a large number cells, the shape of which was controlled with micropatterned substrates [3], in the frequency domain $[4,5]$. The observed AFM data could be analyzed using a power-law structural damping model [6]. We will present the detailed AFM system and discuss the ensemble distribution of power-law rheology parameters between normal and cancer cells.

[1] J. Guck, et al., Biophysical Journal. 88, 3689 (2005)

[2] S. E. Cross, et al., Nat. Nanotech. 2, 780 (2007)

[3] C. Y. Park, et al., Am J Physiol Cell Physiol 298, 1245 (2010)

[4] Y. Mizutani, et al., Jpn. J. Appl. Phys. 47, 6177 (2008)

[5] S. Hiratsuka, et al., Ultramicroscopy 109, 937 (2009)

[6] B. Fabry, et al., Phys. Rev.E, 68, 041914 (2003)

[7] R. Takahashi, et al., in preparation

\section{PS016 "ホッピングモード"高速原子間力顯微(HS-AFM)の開発}

Development of "hopping-mode" high speed atomic force microscopy (AFM)

Hiroki Watanabe ${ }^{1}$, Mikihiro Shibata ${ }^{2}$, Takayuki Uchihashi ${ }^{1,4}$, Ryohei Yasuda $^{3}$, Toshio Ando ${ }^{1,4}$ ('Department of Mathematics and Physics, Grad School of Natural Science and Technology, Kanazawa University, ${ }^{2}$ Department of Neurobiology, Duke University Medical Center, ${ }^{3}$ Max Planck Florida Institute, ${ }^{4}$ Bio-AFM Frontier Research Center, College of Science and Engineering, Kanazawa University)

High-speed AFM (HS-AFM) can directly visualize dynamic behaviors of single protein molecules in action and has recently been proven to be powerful in the elucidation of functional mechanisms of proteins ${ }^{1,2)}$. However, it is hard to observe large and soft biological samples such as live cells and organelles using our tapping-mode HS-AFM because the AFM cantilever tip exerts relatively large lateral forces to the sample during scanning and thus damages soft samples.

To overcome this problem, we attempt to combine a new operation mode of AFM called hopping mode ${ }^{3)}$ with the HS-AFM. In hopping-mode AFM, we no longer use continuous feedback operation. Instead, at each imaging point, the AFM tip approaches the sample from a starting position that is above any of the surface features. The cantilever is freely oscillating when the tip is well away from the surface. The tip then approaches until the amplitude is reduced to a predefined value. When the amplitude experiences this reduction, the position of the z-piezo is recorded as the sample height at this imaging point. Owing to this operation principle, the tip lateral forces applied to the sample can be significantly reduced even for tall samples. In this presentation, we will show the capability of this new AFM system by presenting captured images of HeLa cells.

1) M. shibata et al., Nature Nanotechnol. 5, 208-212 (2010)

2) T. Ucihashi et al., Science 333, 755-758 (2011).

3) P. Noval, C. Li et al., Nature Method 6, 279-281 (2009).

\section{PS017 超音波高速 AFM の開発に向けた基礎研究}

Pilot study for the development of high-speed ultrasonic AFM Yasuto Nagashima', Tomofumi Saito', Noriyuki Kodera ${ }^{2}$, Toshio Ando ${ }^{1,2}$ ('Sch. Math. \& Phys., Inst. Sci. \& Eng., Kanazawa Univ, ${ }^{2}$ Bio-AFM Frontier Research Center, Inst. Sci. \& Eng., Kanazawa Univ)

We have developed high-speed AFM (HS-AFM) that enables us to directly visualize dynamic structural changes of protein molecules at high spatiotemporal resolution. So far, various biological processes performed by protein molecules have been directly filmed as molecular movies, which allowed us to gain insights into their functional mechanisms much more straightforwardly than other techniques [T. Ando, Nanotechnol (2012)]. However, the observations by HS-AFM are generally limited only to phenomena occurring on relatively hard surfaces, meaning that we can observe neither objects placed on a soft surface (e.g., protein molecules on mammalian cell surfaces) nor objects placed under a surface (e. g., organelles and cytoskeletons in the interior of cells). Ultrasonic techniques must be useful in breaking this limitation because they have been widely used for noninvasiveness imaging of objects lying on/under a surface, whereas their spatial resolution is limited by the wavelength of ultrasonic used. However, AFM which is combined with ultrasonic techniques is recently claimed to be able to perform subsurface imaging of objects in the interior of cells at nanometer resolution [GS. Shekhawat \& VP. Dravid, Science (2005)]. Thus, we are currently attempting to find a way to combine our HS-AFM with ultrasonic techniques. In the presentation, we will report our pilot study on this subject. 
AFM studies on the spread films of protein

Taiji Furuno (Dept. Phys., Keio Univ. Sch. Med.)

The spread films of protein at the air/water interface hold almost hundred years of research history. The surface properties of them have been mainly discussed based on the pressure-area isotherms. However, the study lacks the direct structural information on the state of the spread protein molecules.

The invention of atomic force microscope (AFM) has opened the avenue to study single proteins or protein assemblies in water if they were deposited on smooth solid surfaces. In the present study, a number of proteins have been directly spread on the water surface using a $10 \mathrm{uL}$ microsyringe with its needle end touching the water surface. The surface films were transferred onto hydrophobic silicon surface and imaged by tapping mode AFM under water. They were classified into three groups. Catalase, carbonic anhydrase, ferritin and apoferritin, which denatured gradually after spreading, formed two-dimensional random packing in the spread films. In the second group to which bovine serum albumin and thermally treated carbonic anhydrase belonged, the unfolding was very quick at the air/water interface, and almost no granular particles corresponding to the spread protein molecules were not found bound to or embedded in the film. The third group consisted of lysozyme and streptavidin, which resisted to be spread at the interface, and were mostly lost into the subphase. All these classifications were possible by AFM imaging of the transferred films.

\section{PS019 カーボンナノチューブ電檽を用いた神経伝達物質の高感度記録法の 開発}

Development of Carbon Nanotube Electrode For High Sensitivity Recordings of Neurotransmitters

Mao Fukuda, Ikurou Suzuki, Masao Gotoh (Department of Bionics, Graduate School of bionics, computer and media science Tokyo University of Technology)

We have developed a microelectrode array chip and paste electrode that can measure neurotransmitters. In this study, we focused on using carbon nanotubes because they indicate high conductivity, and changeable in physical properties. A 64 planner electrodes were fabricated by etching an indium-tin oxide (ITO) layer on a glass slide, then covered with insulating film. The surface of recording terminals was formed by etching the insulating film to $50 \mu \mathrm{m}$ in diameter and was then coated with single-wall carbon nanotube (SWCNT) and multi-wall carbon nanotube (MWCNT) of bamboo-type or HC-type by electroplating. On the other hand, the paste electrode was fabricated by filling it with mixed carbon nanotube dispersion. Using these carbon nanotube microelectrode array chip and paste electrodes, we successfully detected their response to $(10 \mathrm{nM})$ of dopamine, acetylcholine, and serotonin. These results suggest that the microelectrode array chip have the potential for real-time recordings of neurotransmitters.

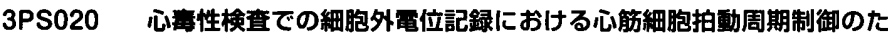 めの電気刺激方法の最通化}

Optimization of electrical stimulation protocol for cardiac beat control with extracellular potential measurement in cardiotoxicity test

Tomoyuki Kaneko, Fumimasa Nomura, Tomoyo Hamada, Kenji Yasuda (Dept. Biomed. Inform., IBB, TMDU)

The QT prolongation in electrocardiogram is recognized as a potential risk associated with the use for cardiotoxicity testing. Recently, cardiomyocytes derived from human embryonic stem cell (hESC) have been applied for in vitro cardiotoxicity testing, in which QT prolongation risk is estimated by the prolongation of drug-induced change of the field potential duration (FPD) in onchip extracellular potential measurement assay. As this in vitro assay usually uses unstable spontaneous beating cardiomyocytes, the precise beat-to-beat correction procedure of in vivo $\mathrm{QT}_{\mathfrak{c}}$ measurement was not applied for this unstable FPD data. To overcome this problem, we have examined the effective electrical stimulation protocols for cardiomyocyte beating interval control with smallest influence to continuous extracellular potential measurement. First, by applying the simple bipolar stimulation with same amplitude of positive and negative voltages, the artifacts in electrical stimulation were too large and long to record the extracellular field potentials of cardiomyocytes after each stimulation. In contrast, the sequential short rectangular pulses with the balanced positive and negative pulses caused to record the sharp negative artifact only, which was little and short influence to measure the FPD of cardiomyocytes. The results indicate that the balanced applied voltages and pulse numbers are desirable to minimize the artifacts and to respond the hESC- derived cardiomyocyte clusters by electrical stimulation with extracellular potential measurement.

\section{PS021 イオン移動ボルタンメトリーに基づく敞量ペプチドの物質量決定}

Determination of mole number for trace amount of a peptide based on the ion transfer voltammetry

Yumi Yoshida, Yoshiro Morita, Shotaro Nakamura, Junya Uchida, Kohji Maeda (Department of Chemistry and Materials Technology, Kyoto Institute of Technology)

Most of quantitative analytical methods require a calibration curve made of the reference material of analyte, of which mole number is usually determined by weight measurement. For trace amount of biological compound such as peptides and proteins, its weight is too little to determine its mole number. Usually, these compounds are decomposed into short peptides, amino acids or $\mathrm{N}$ element, and these decomposition products are determined using a calibration curve of low molecular substances which is weighable. These procedures are complicate and should be carried out with respect to each compound. In contrast, electrochemical method is the most powerful method to determine mole number without weight measurement, in which mole number is estimated according to Faraday's law. In the present work, we propose mole number determination based on the ion transfer voltammetry, in which an ionic molecule transfer from aqueous sample, $\mathrm{W}$, to organic phase, Org, by applying interfacial potential at the $\mathrm{W} \mid \mathrm{Org}$ interface, and the ion transfer is detected as current. Total charge, $\mathrm{Q}$, of current gives mole number, $n$, of the ionic molecule based on Faraday's low, $\mathrm{n}=\mathrm{Q} / \mathrm{zF}$. Here, $\mathrm{z}$ and $\mathrm{F}$ are valence of the ionic molecule and Faraday constant. As an ionic molecule, we tried to determine mole number of some short peptides such as Lys-Leu-Val-Phe-Phe.

\section{PS022 リング状敞小電樰上の心䯇細胞の環状細胞ネットワークを用いた心 毒性検㚗技術}

On-chip quasi-in vivo cardiac toxicity assay using ring-shaped closed circuit microelectrode with lined-up cardiomyocyte network

Fumimasa Nomura, Tomoyuki Kaneko, Tomoyo Hamada, Kenji Yasuda (Inst. of Biomaterials \& Bioengineering, Tokyo Medical \& Dental Univ.)

Re-entry of excitation in heart is one of the abnormal phenomena to cause the lethal arrhythmia and is thought to be induced by the looped structure of excitation conduction pathway. For adaptable preclinical strategies to evaluate global cardiac safety, an on-chip quasi-in vivo cardiac toxicity assay for lethal arrhythmia measurement using ring-shaped closed circuit microelectrode chip has been developed. The ventricular electrocardiogram (ECG) -like field potential data, which includes both the repolarization and the conductance abnormality, was acquired from the self-convolutied extracellular field potentials (FPs) of a lined-up mouse embryonic cardiomyocyte network on a circle-shaped microelectrode in an agarose microchamber. When E4031 (hERG blocker, positive control) and Astemizole (false-negative drug in vitro assay) applied to the closed-loop cardiomyocyte network, self-convoluted FP profile of normal beating changed into an early afterdepolarization (EAD) like waveform, and then showed ventricular tachyarrhythmias and ventricular fibrilations (VT/Vf). QT-prolongation-like self-convoluted FP duration prolongation and its fluctuation increase ware also observed according to the increase of Astemizole concentration. The results indicate that the convoluted FPs of the quasi-in vivo cell network assay includes both of the repolarization data and the conductance abnormality of cardiomyocyte networks has the strong potential to prediction lethal arrhythmia.

\section{$3 P S 023$ 細盷外電位解析と光学イメージング解析を組み合わせた心機能計測 解析システムの開発}

Development of Dual Recording Assay for Cardiac Function Measurement using Electrical Field Potential and Optical Image Analysis

Toru Shoji, Tomoyuki Kaneko, Fumimasa Nomura, Akihiro Hattori, Kenji Yasuda $(B M I, I B B, T M D U)$

In drug assessment of cardiac safety, development of mechanophysiological effects on cardiomyocytes caused by false positive/negative compounds has becoming more important to acquire more precise prediction of cardiotoxicity. For the evaluation of correlation between mechanophysiological effects and electrophysiological effects against drugs, we have developed a dual 